\title{
Acute respiratory flow restriction affects average power, but not heart rate and subjective perceived exertion in healthy women
}

\author{
A restrição aguda do fluxo respiratório afeta a potência média, mas não a frequência \\ cardíaca e a percepção subjetiva do esforço de mulheres saudáveis \\ La restricción aguda del flujo respiratorio afecta la potencia promedio, pero no la \\ frecuencia cardíaca y el esfuerzo subjetivo percibido en mujeres sanas
}

Rousseau Silva da Veiga* (D) , Camila Borges Müller ${ }^{a}$ (D) , Gustavo Dias Ferreira ${ }^{a}$ (D), Eraldo dos Santos Pinheiro ${ }^{a}$ id, Fabrício Boscolo Del Vecchio ${ }^{a}$

\section{Keywords:}

Physical exercise;

Athletic performance;

High intensity interval

training;

Ventilatory flow.

\begin{abstract}
This study aims to verify the effect of the restriction of the ventilatory flow on HR, RPE, and power during HIT-test performed by healthy women. The participants $(n=8)$ underwent HITtest without and with ventilatory flow restriction. HR, power, and RPE was measured. HRpost showed no significant difference between conditions $(p=0,053)$. The average power presented higher values in the condition without the restriction of ventilatory flow $(619,51 \pm 144,33 \mathrm{~W}$; $565,99 \pm 108,43 W ; p=0,001)$, but without differences in the fatigue index $(p=0,383)$. In both conditions, increases in RPE were observed during the efforts $(p<0,001)$. It is concluded that $\mathrm{HR}$ and RPE did not suffer acute effects from the restriction of ventilatory flow; however, the average power is decreased during HIT-test.
\end{abstract}

Palavras-chave: Exercício físico; Desempenho atlético; Treinamento intervalado de alta intensidade; Fluxo ventilatório.

Palabras-clave: Ejercicio físico; Desempeño atlético; Entrenamiento por intervalos de alta

\section{RESUMO}

O objetivo do estudo foi verificar o efeito da restrição do fluxo ventilatório na FC, PSE e potência durante o HIT-teste realizado por mulheres saudáveis. As participantes $(n=8)$ foram submetidos ao teste HIT sem e com restrição do fluxo ventilatório. HR, potência e PSE foram medidos. FCpos não apresentou diferença significativa entre as condições $(p=0,053)$. A potência média mostrou valores maiores na condição sem restrição do fluxo ventilatório $(619,51 \pm 144$,33W; $565,99 \pm 108,43 W ; p=0,001)$, mas sem diferenças no índice de fadiga $(p=0,383)$. Em ambas as condições, foram observados aumentos da PSE durante os esforços $(p<0,001)$. Conclui-se que a FC e a PSE não sofreram efeitos agudos da restrição do fluxo ventilatório; no entanto, a potência média diminui durante o HIT-teste.

\section{RESUMEN}

El objetivo del estudio fue verificar el efecto de la restricción del flujo ventilatorio sobre la FC, PSE y potencia durante la prueba HIT realizada por mujeres sanas. Las participantes $(n=8)$ se sometieron a la prueba HIT sin y con flujo de ventilación restringido. Se midieron la FC, la potencia y la PSE. FCpos no mostró diferencias entre las condiciones $(p=0,053)$. La potencia promedio mostró valores más altos sin restricción de flujo ventilatorio $(619,51 \pm 144,33 W$; $565,9 \pm 108,43 W ; p=0,001)$, pero no en el índice de fatiga $(p=0,383)$. En ambas condiciones, se observaron aumentos de PSE durante los esfuerzos $(p<0,001)$. Se concluye que la FC y la PSE no sufrieron efectos agudos de la restricción del flujo ventilatorio; sin embargo, la potencia media disminuye en la prueba HIT.

aUniversidade Federal de Pelotas - UFPel. Pelotas, RS, Brasil.

\footnotetext{
*Autor correspondente:

Rousseau Silva da Veiga

E-mail: rousseauveiga@gmail.com 
intensidade;

Flujo ventilatório.

\section{INTRODUCTION}

High-intensity interval training (HIIT) is characterized by sessions in which stimuli are applied above the anaerobic threshold intermittently (Gibala and McGee, 2008; Lucas et al., 2018). Repeated sprints training (RST) stands out among the different models of high-intensity intervals by differing from other traditional training methods, especially addressing continuous exercise, for its ability to generate similar benefits, despite of the less time employed (MacPherson et al., 2011). The RST usually involves a reduced effort duration (<10s), followed by recovery periods (<60s), and is widely used in collective modalities due to its action intermittency (Woorons et al., 2017) and capacity to develop the ability to repeat sprints (Bishop et al., 2011). The RST exercise is predominantly aerobic and some of its protocols have a sharp power decrease during the efforts (Woorons et al., 2017).

The RST can be performed for various implements and/or environments, including use for body mass only or as a reference for defining the possible training overload (Uthoff et al., 2020), enabling intensity control in several ways, such as heart rate (HR) (Abad et al., 2019), power produced, and rate perceived effort (RPE) (Gibala, 2009). Several researchers have based their studies on this exercise model worldwide (Gibala and McGee, 2008; Woorons et al., 2017) seeking to achieve more consistent foundations for their outcomes by testing their effects on different physiological conditions, such as in situations of total oxygen flow restriction, known as anoxia (Wen et al., 2018), which is often related to clinical conditions (Krivoruchko and Storey, 2015) or even hypoxia (Dall'Agnol and Del Vecchio, 2018). This latter condition consists of lower oxygen availability in the tissues and can be caused during ascension to altitude or simulated with specific equipment for this purpose (Oliveira et al., 2017).

Recent studies addressing RST and hypoxia have been introduced as performance comparison means for exercises with or without restricted oxygen flow, demonstrating chronic improvements like muscle perfusion (Faiss et al., 2013; Montero and Lundby, 2017), changes in the proportion of type IIx muscle fibers (De Smet et al., 2016), enhanced anaerobic metabolism (Faiss et al., 2013; Puype et al., 2013), and increased muscle buffering capacity (Faiss et al., 2013).

Furthermore, equipment that restricts respiratory flow to simulate altitude has been used in different contexts, such as football, martial arts, and recreational activities like CrossFit (Jung et al., 2019). However, the information obtained still has specific limitations, such as samples composed exclusively by men, decrease in physical performance within the same training session unmeasured, and equipment influence on the perceived effort unreported, suggesting that the topic is yet to be further explored. Thus, our goal was to verify the effect of ventilatory flow restriction on HR, PSE, and power during intermittent high-intensity test performed by healthy women. By searching the scientific literature, we strongly believe that ventilatory flow restriction will not influence variables such as HR and RPE. However, concerning the power, our hypothesis is the occurrence of a drop-in performance in the final efforts and the average power produced.

\section{MATERIALS AND METHODS}

\section{TYPE OF STUDY AND SUBJECTS}

Our sample has an experimental blind design, elaborated through counterbalanced randomization in blocks of two people. The sample includes 8 women with an average age of $21.37 \pm 2.55$ years, height of 1.65 $\pm 0.7 \mathrm{~cm}$, body mass of $61.23 \pm 6.54 \mathrm{~kg}$, and body mass index of $26.80 \pm 3.27$, selected based on convenience considering the availability in the participants' schedule. The following inclusion criteria were applied: participants should be healthy, not make use of any ergogenic supplement or have any previous injury that prevented or interfered with the performance during the tests. An initial anamnesis procedure provided us with this information. All those that, for some reason, exceeded 48 $\mathrm{h}$ between test and retest or reported anginophobia and claustrophobia during the experiment were excluded. All participants were informed about the research risks, read and signed a free and informed consent form. This study was approved by the Research Ethics Committee of the Federal University of Pelotas under registration 68577917.0.1001.5313.

\section{EXPERIMENTAL APPROACH TO THE PROB- LEM}

We subjected the participants to a high-intensity intermittent test protocol (HIT-Test) randomly according to the following two conditions: with restriction (WITH-R) and without restriction of ventilatory flow (WITHOUT-R), with intervals between $36 \mathrm{~h}$ and 48 $\mathrm{h}$ among them to minimize the influence of the first session on the subsequent meeting. The randomization involved blocks of three people based on the guidelines of Cummings et al. (1998), in which the first block was WITHOUT-R.

In order to be evaluated, the participants should present themselves adequately fed, having had their last meal between $60 \mathrm{~min}$ and $90 \mathrm{~min}$ before physical effort, and slept between $8 \mathrm{~h}$ and $10 \mathrm{~h}$ the night before, in addition to having not practiced high-intensity effort over the previous $24 \mathrm{~h}$. Laboratory conditions were maintained constant, at $21^{\circ} \mathrm{C}$ and $60 \%$ relative humidity (Veiga et al., 2020). 


\section{HIGH-INTENSITY INTERMITTENT TEST}

We performed a HIT-test in both the WITH-R and WITHOUT-R conditions, using a cycle ergometer model Biotec 2100 by CEFISE $^{\circledR}$ (Santa Bárbara D’oeste, Brazil), with specific prior heating with a free cadence and a load of $0.5 \mathrm{~kg}$ for $2 \mathrm{~min}$. The load used during the tests was defined individually, considering $7.5 \%$ of the body mass per sample component (Al Haddad et al., 2012). The HITtest used consisted of a series of $6 \mathrm{~s}$ sprints with all-out efforts, which included verbal stimuli during the action, and a $24 \mathrm{~s}$ passive rest between each sprint (McGawley and Bishop, 2006). We estimated a total of 15 sets, ending the session at $7 \mathrm{~min}$ and $30 \mathrm{~s}$ of duration.

\section{WITH-R PROTOCOL}

During the performance of the WITH-R test, we performed the same HIT-test applied in the WITHOUT-R condition, but using a specific mask (Masks (C) for restricting the ventilatory flow in the WITH-R (Training Elevation Mask 3.0, Cadillac, $\mathrm{MI}$ ), with a relative restriction simulation of $3.657 \mathrm{~m}$ of altitude. The participants were subjected to an adaptation period of $5 \mathrm{~min}$ in the sitting position without making any effort. At this moment, if any participant reported any discomfort with the instrument, participation would be unabled and exclusion from the study would be applied.

\section{DATA COLLECTIONS}

Before the sessions, the participants went through a 5 min-sitting period to allow for measuring the resting heart rate (HRrest), followed by familiarization with the test and presentation of the RPE scale used in the experiment. The HR was also monitored throughout the HIT-test procedure generating the values referring to the average HR (HRmean) and immediately after (HRpost), variables obtained using the cardiac monitor Polar ${ }^{\circledR}$, model H7 (Kempele, Finland).
We recorded the power production during and in the end of each sprint on the Ergometric 6.0 software (Cefise, Santa Bárbara D'oeste, Brazil), simultaneously with the RPE values measurement according to the 6-20 scale (Borg, 1982).

\section{STATISTICAL ANALYSIS}

We carried out a Shapiro-Wilk test to verify data normality, and a two-way ANOVA with Bonferroni's posthoc for differences and interactions between HRrest and HRpost with and without oxygen flow restriction. In turn, a factorial ANOVA with repeated measurements compared the conditions of restriction and stimuli, as well as their interactions in produced power. A paired t-test was applied to compare average power output and fatigue index between conditions, while for RPE, non-parametric statistics were used using the Wilcoxon test. The estimated values of effect size (ES) were calculated from Cohen's $d$, according to the following classifications: trivial $(\leq 0.20-$ $0.49)$, moderate $(0.50-0.79)$, and great $(\geq 0.80)$. Finally, we also used t-test to compare the area under the AUC curve on the GraphPad Prism software, version 6.01.

\section{RESULTS}

The pre and post-test HR averages in WITHOUT-R were $66.50 \pm 7.23 \mathrm{bpm}$ and $167.88 \pm 9.11 \mathrm{bpm}$, respectively. In the WITH-R condition, the averages were $67.13 \pm 8.58 \mathrm{bpm}$ and $176.75 \pm 8.75 \mathrm{bpm}$ for pre- and post-tests, respectively. Therefore, despite the higher HR values in the WITH-R, no significant difference appeared $(F=5.423 ; p=0.053 ; E S=0.36)$, having occurred only before and after the test $(F=1138.437 ; p<0.001)$.

The average power produced (Figure 1) during WITH-R efforts was statistically lower than in the test performed without restriction $(F=28.527 ; p=0.001)$. Besides, power was significantly attenuated during the efforts in both conditions ( $F=27.097 ; p<0.001)$.

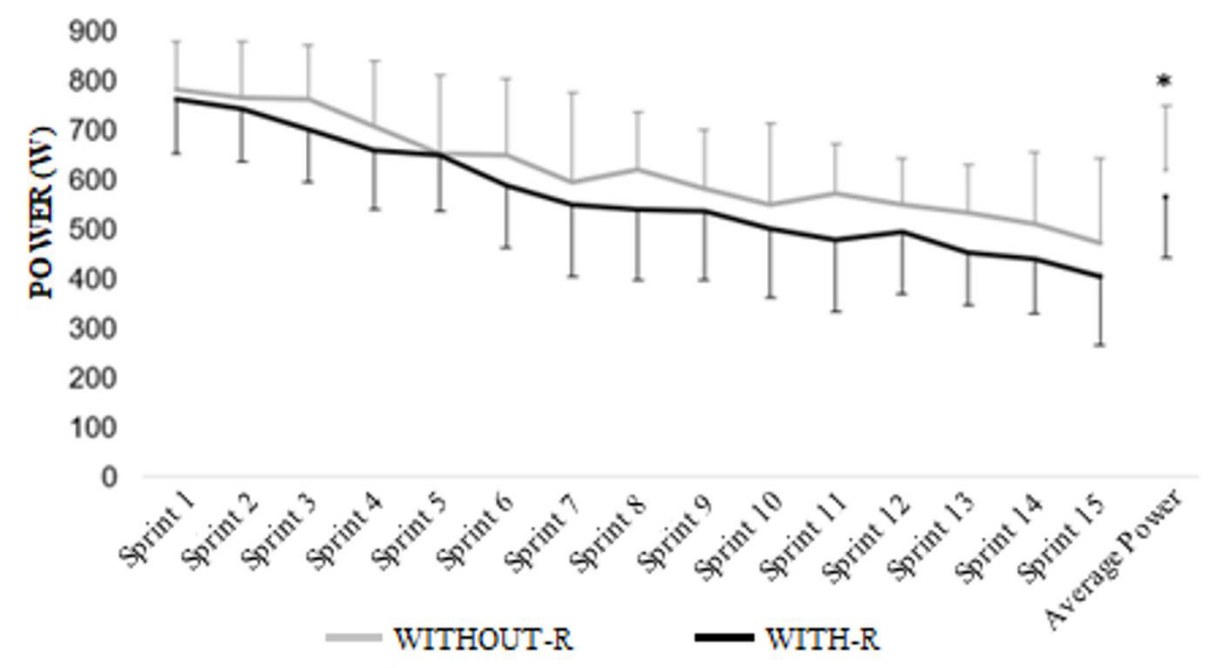

Figure 1. The power produced in the HIT-test performed without and with restricted oxygen flow. *Statistically different from the WITHOUT-R condition $(\mathrm{p}<0.001)$. 


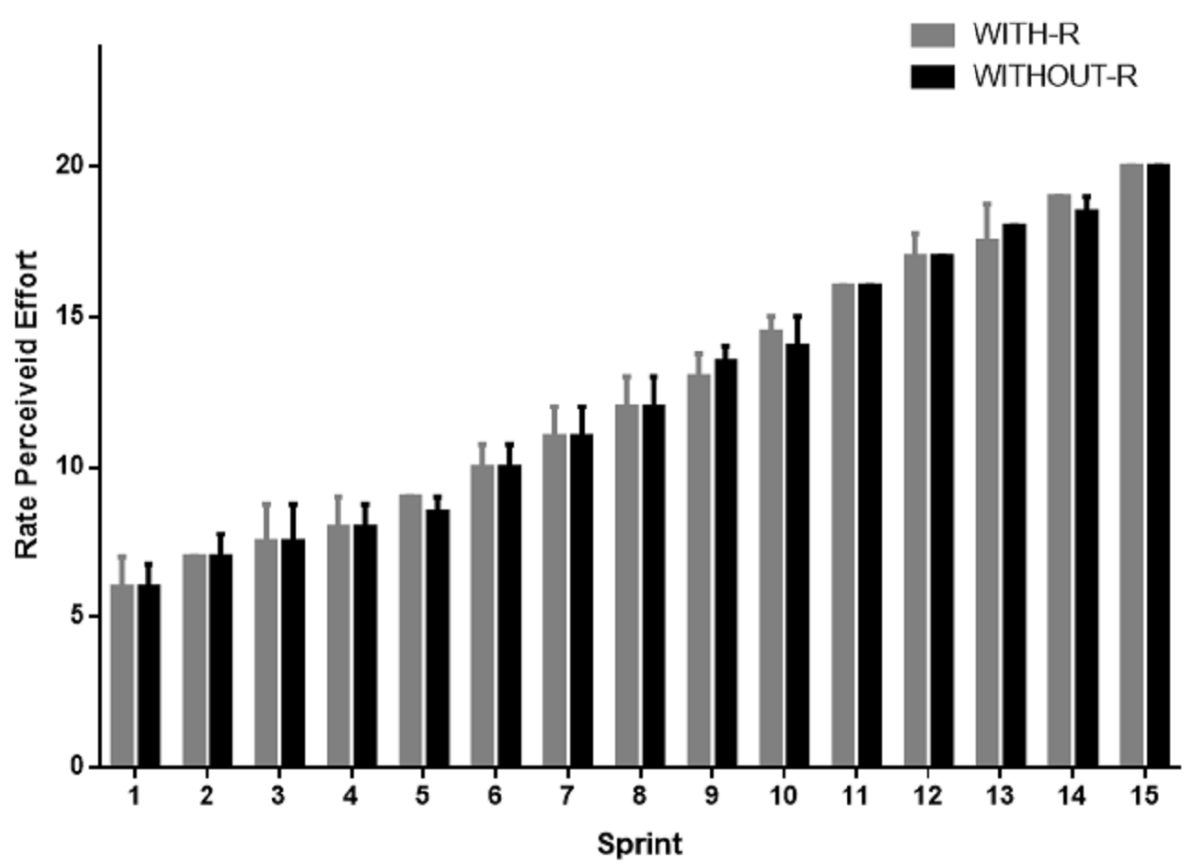

Figure 2. Rate perception of effort during the protocol. (a) statistically different from the other WITHOUT-R series; (b) statistically different from the other WITH-R series.

The average power generated in WITHOUT-R was $619.51 \pm 114.33 \mathrm{~W}$, and $565.99 \pm 108.43 \mathrm{~W}$ in WITH-R, with significant differences between conditions $(p=0.001$; $E S=0.36)$. In contrast, the fatigue index did not show significant differences $(p=0.383 ; E S=-0.10)$ between the WITHOUT-R (-309.76 $\pm 175.68 \mathrm{~W} ; 39.62 \%)$ and WITH-R $(-357.66 \pm 178.31 \mathrm{~W} ; 46.95 \%)$ protocols. The area under the power curve reveals a behavior of both conditions considered moderate for the efforts in WITH-R and WITHOUT-R (AUC $=0.66$ ).

Although, the RPE (Figure 2) had a similar behavior when performed with and without restriction $(Z=-0.962$; $p=0.336, E S=0.10)$, significant increases in RPE appeared during the efforts in both conditions $(Z=-2.549$; $p=0.011$ ).

\section{DISCUSSION}

Our purpose was to verify the effect of ventilatory flow restriction on the intermittent performance of healthy women. Our main finding is the absence of a significant reduction in power values between intermittent efforts, with reduced average power values, in addition to the absence of differences in the HRpost test and RPE in both of the conditions studied.

Initially, we found that even though both the conditions proposed in this study caused a significant increase in HR between pre- and post-test moments, no differences appeared between the efforts with or without the ventilatory flow restriction. Al Haddad et al. (2012) investigated cardiovascular parameters in 10 healthy men during 20s intermittent supramaximal efforts, like in this study, and pointed out that acute exposure to ventilatory flow restriction did not generate changes in HR after exercise. The effect of lack of ventilation on HR was related to the short exposure time and low intensity in the test. In turn, Porcari et al. (2016) followed 24 recreationally active men, divided into two groups (with restriction and without restriction of oxygen flow), subjected to high-intensity training for 6 weeks, twice a week. The authors did not find any significant differences between conditions when isolating the results of the first ventilatory flow restriction session (at a simulated altitude of $912 \mathrm{~m}$ ), the same behavior found in the 11 subsequent sessions. Accordingly, Buchheit et al. (2004) subject 12 men to hypoxia in a state of rest and exercise performed at $50 \%$ of iVO2max, and reported no significant differences in either situation, strongly demonstrating that hypoxia may have little influence on this physiological marker. Such finding is in line with the data found in this study, since the HR did not present significant changes between the conditions. These outcomes may have resulted from the implementation of oxygen restriction associated with the short period of effort and prolonged rest, which is likely to have not been sufficient to generate differences and resulted in a predominance of the sympathetic nervous system in relation to the parasympathetic, in both conditions similarly (Vaz et al., 2014).

Meeuwsen et al. (2001) conducted a study with 16 subjects randomized into two groups: one with hypoxia training (simulated altitude of $2500 \mathrm{~m}$ ) and the other without, both with intensities between 60 and $70 \%$. The performance variable adopted was the power produced during the Wingate test performed before and after the intervention. In the end of the baseline consolidation, no 
significant differences between conditions immediately were found after the high-intensity intermittent effort. The authors concluded that only 9 days after a difference appeared between the conditions of this parameter. Faiss et al. (2013) found the same behavior when proposing an intermittent effort protocol consisting of 3 series of repeated sprints $(5 \times 10$ s all-out with a 5 min-recovery period at $120 \mathrm{~W}$ between stimuli), in which no differences occurred between conditions, thus corroborating our results. A factor to be considered regarding the similar results is the substantially shorter effort period in relation to the recovery. High intensity and short duration efforts involve the use of energy from the ATP-CP system, whose oxygen is not required to break the molecule and release energy. However, ATP resynthesis is required, therefore, it is believed that the effort exposure time in both studies led to low energy wear in the above-mentioned system.

Borg (1982) defines the RPE as the subjective intensity of effort, tension, discomfort, and/or fatigue experienced during physical exercises, whether aerobic or strength. In this study, the RPE values showed similar dynamics when performed with or without ventilatory flow restriction. Faiss et al. (2013) conducted a study to evaluate healthy men and found RPE averages of $16.2 \pm 1.4$, and $16.7 \pm 1.5$ for HIT-test with and without ventilatory flow restriction, respectively. Evidence has suggested that making efforts at simulated altitude can increase fatigue due to an abrupt $\mathrm{Pi}$ accumulation during stimuli and removal rate during recovery (Faiss et al., 2013). However, the participants in this study did not report strongly different RPE values between conditions, possibly due to the intensity of the efforts employed in the different conditions being all-out in an effort: pause ratio 1:4, which, in theory, allows for a slight recovery, thus enabling a similar perceived effort between conditions.

The low $\mathrm{N}$ sample is the main limitation of this study, a factor that can affect the results of this type of study. However, we believe such bias to be have been attenuated by the randomization of the authors' conditions, in addition to the precise measurements.

It is now feasible for trainers and fitness coaches to use the Training Elevation Mask 3.0 in RST protocols aimed at power work, since despite the lower average power, the performance between efforts remained constant, thus not compromising the training session.

\section{CONCLUSION}

According to our data, we conclude that neither the HR or the RPE suffered from the effects of ventilatory flow restriction. However, the total session performance in the HIT-test measured from the average power produced decreases with the application of Training Elevation Mask 3.0. Additionally, performance remained constant between subsequent intermittent efforts.
Further studies should investigate and explore a different effort:pause than the one used in this study to identify whether the relationship with approximate times is capable of generating different organic stress.

\section{FUNDING}

This work has not received financial support of any kind for its realization.

\section{CONFLICTS OF INTEREST}

The authors declare no conflicts of interest.

\section{REFERENCES}

Abad CCC, Pereira LA, Zanetti V, Kobal R, Loturco I, Nakamura FY. Short-term cardiac autonomic recovery after a repeated sprint test in young soccer players. Sports. 2019;7(5):102. http://dx.doi.org/10.3390/sports7050102. PMid:31052145.

Al Haddad H, Mendez-Villanueva A, Bourdon PC, Buchheit M. Effect of acute hypoxia on post-exercise parasympathetic reactivation in healthy men. Front Physiol. 2012;3:289. http://dx.doi.org/10.3389/fphys.2012.00289. PMid:22934041.

Bishop D, Girard O, Mendez-Villanueva A. Repeated-sprint ability - part II: recommendations for training. Sports Med. 2011;41(9):741-56. http://dx.doi.org/10.2165/11590560000000000-00000. PMid:21846163.

Borg GAV. Psychophysical bases of perceived exertion. Med Sci Sports Exerc. 1982;14(5):377-81. http:// dx.doi.org/10.1249/00005768-198205000-00012. PMid:7154893.

Buchheit M, Richard R, Doutreleau S, Lonsdorfer-Wolf E, Brandenberger G, Simon C. Effect of acute hypoxia on heart rate variability at rest and during exercise. Int J Sports Med. 2004;25(4):264-9. http://dx.doi. org/10.1055/s-2004-819938. PMid:15162245.

Cummings SR, Black DM, Thompson DE, Applegate WB, Barrett-Connor E, Musliner TA, et al. Effect of alendronate on risk of fracture in women with low bone density but without vertebral fractures. Results from the fracture intervention trial. JAMA. 1998;280(24):2077-82. http:// dx.doi.org/10.1001/jama.280.24.2077. PMid:9875874.

Dall'Agnol C, Del Vecchio F. Blood flow restriction training: concerning a literature review. ConScientiae Saúde. 2018;17:109.

De Smet S, Van Thienen R, Deldicque L, James R, Sale C, Bishop DJ, et al. Nitrate intake promotes shift in muscle fiber type composition during sprint interval training in hypoxia. Front Physiol. 2016;7:233. http://dx.doi.org/10.3389/ fphys.2016.00233. PMid:27378942.

Faiss R, Girard O, Millet GP. Advancing hypoxic training in team sports: From intermittent hypoxic training to repeated sprint training in hypoxia. $\mathrm{Br} J$ Sports Med. 2013;47(Suppl. 1):i45-50. http://dx.doi.org/10.1136/ bjsports-2013-092741. PMid:24282207. 
Gibala M. Molecular responses to high-intensity interval exercise. Appl Physiol Nutr Metab. 2009;34(3):428-32. http://dx.doi.org/10.1139/H09-046. PMid:19448710.

Gibala MJ, McGee SL. Metabolic adaptations to short-term high-intensity interval training: A little pain for a lot of gain? Exerc Sport Sci Rev. 2008;36(2):58-63. http://dx.doi. org/10.1097/JES.0b013e318168ec1f. PMid:18362686.

Jung $\mathrm{HC}$, Lee $\mathrm{NH}$, John SD, Lee $\mathrm{S}$. The elevation training mask induces modest hypoxaemia but does not affect heart rate variability during cycling in healthy adults. Biol Sport. 2019;36(2):105-12. http://dx.doi.org/10.5114/ biolsport.2019.79976. PMid:31223186.

Krivoruchko A, Storey KB. Turtle anoxia tolerance: biochemistry and gene regulation. Biochim Biophys Acta, Gen Subj. 2015;1850(6):1188-96. http://dx.doi.org/10.1016/j. bbagen.2015.02.001. PMid:25662819.

Lucas IS, Raiol R, Farias DA, Coswig V. Respostas neuromusculares ao treinamento de sprints. Rev Bras Prescrição e Fisiol Do Exerc. 2018;12:624-31.

MacPherson REK, Hazell TJ, Olver TD, Paterson DH, Lemon PWR. Run sprint interval training improves aerobic performance but not maximal cardiac output. Med Sci Sports Exerc. 2011;43(1):115-122. http://dx.doi. org/10.1249/MSS.0b013e3181e5eacd. PMid:20473222.

McGawley K, Bishop D. Reliability of a $5 \times 6$-s maximal cycling repeated-sprint test in trained female team-sport athletes. Eur J Appl Physiol. 2006;98(4):383-93. http://dx.doi. org/10.1007/s00421-006-0284-8. PMid:16955291.

Meeuwsen T, Hendriksen IJM, Holewijn M. Training-induced increases in sea-level performance are enhanced by acute intermittent hypobaric hypoxia. Eur J Appl Physiol. 2001;84(4):283-90. http://dx.doi.org/10.1007/ s004210000363. PMid:11374111.

Montero D, Lundby C. Refuting the myth of non-response to exercise training: 'non-responders' do respond to higher dose of training. J Physiol. 2017;595(11):3377-87. http:// dx.doi.org/10.1113/JP273480. PMid:28133739.
Oliveira ALMB, Rohan PA, Gonçalves TR, Soares PPS. Efeitos da hipóxia na variabilidade da frequência cardíaca em indivíduos saudáveis: uma revisão sistemática. Int J Cardiovasc Sci. 2017;30:251-61.

Porcari JP, Probst L, Forrester K, Doberstein S, Foster C, Cress $\mathrm{ML}$, et al. Effect of wearing the elevation training mask on aerobic capacity, lung function, and hematological variables. J Sports Sci Med. 2016;15(2):379-86. http:// dx.doi.org/10.1249/01.mss.0000488131.38685.16. PMid:27274679.

Puype J, Van Proeyen K, Raymackers JM, Deldicque L, Hespel P. Sprint interval training in hypoxia stimulates glycolytic enzyme activity. Med Sci Sports Exerc. 2013;45(11):216674.

Uthoff A, Oliver J, Cronin J, Harrison C, Winwood P. Sprintspecific training in youth: backward running vs forward running training on speed and power measures in adolescent male athletes. J Strength Cond Res. 2020; 34(4):1113-1122.

Vaz, MS, Picanco, LM, Del Vecchio, FB. Effects of different training amplitudes on heart rate and heart rate variability in young rowers. J. Strength Cond Res. 2014; 28(10):29672972.

Veiga RS, Müller CB, Cabistany LD, Formalioni AC, Pinheiro ES, Vecchio FBD. The validity of Keiser-M3 stationary bicycle with standard ergometer for physiological measurements associated with maximum effort. Motriz Rev Educ Fis. 2020;26(2):1-8. http://dx.doi.org/10.1590/s19806574202000020196.

Wen XH, Li Y, Han D, Sun L, Ren PX, Ren D. The relationship between cognitive function and arterial partial pressure $\mathrm{O} 2$ in patients with COPD: A meta-analysis. Medicine. 2018; 97(4):e9599.

Woorons X, Mucci P, Aucouturier J, Anthierens A, Millet GP. Acute effects of repeated cycling sprints in hypoxia induced by voluntary hypoventilation. Eur. J. of Appl. Physiol. 2017;117(12):2433-2443. 